\title{
Article \\ Freedom of Worship during a Public Health State of Emergency in France
}

\section{Anne Fornerod}

Citation: Fornerod, Anne. 2021. Freedom of Worship during a Public Health State of Emergency in France. Laws 10: 15. https://doi.org/ 10.3390/laws10010015

Received: 12 January 2021 Accepted: 20 February 2021 Published: 25 February 2021

Publisher's Note: MDPI stays neutral with regard to jurisdictional claims in published maps and institutional affiliations.

Copyright: (C) 2021 by the author Licensee MDPI, Basel, Switzerland. This article is an open access article distributed under the terms and conditions of the Creative Commons Attribution (CC BY) license (https:// creativecommons.org/licenses/by/ $4.0 /)$.
National Center for Scientific Research, University of Strasbourg, 67083 Strasbourg, France; anne.fornerod@misha.fr

\begin{abstract}
This paper analyses three key decisions issued by the French State Council in 2020 following emergency proceedings concerning the impact of pandemic-related measures on the freedom of worship. The Council interestingly recalls that the freedom of worship is a fundamental freedom, but shows, too, how it is influenced by circumstances when determining whether the measures limiting the freedom to practice one's religion are proportionate to the goal of protecting public health.
\end{abstract}

Keywords: state of emergency; freedom of religion; French law and religion

\section{Introduction}

Along with the vast majority of countries, France has managed the health crisis by limiting, and in some cases prohibiting, the exercise of certain civil liberties ${ }^{1}$. Rights and freedoms related to individuals as physical beings have been the primary focus, whereas the rights and freedoms of the mind have continued to be protected. This Cartesian division between mind and body contrasts with "the oneness of life, which is always inseparably physical and spiritual at the same time", and splits us into "purely biological organisms on the one hand," and "affective, cultural [beings] on the other"2. This description fits the impact of the state of emergency on the freedom of religion perfectly. By denying the right to worship, the government has severely curtailed the freedom of religion while leaving the freedom of conscience intact. The lockdown has turned society upside down and reconfigured values by giving priority to what is deemed, by the executive branch, "essential to the continuity of the life of the Nation" (Article 7, decree no. 2020-293 of 23 March 2020 setting out the general measures needed to manage the COVID-19 epidemic in the context of the public health state of emergency). Limiting funeral rites to the strict minimum showed that the "continuity" in question is first and foremost "biological". As a result, social life has been largely structured around a distinction between what is necessary to that continuity and what is not ${ }^{3}$. No exception was made for the freedom to worship, so religious services were cancelled along with numerous other activities. I will focus here on places of worship-places built specifically for exercising the freedom of worship-to determine what repercussions the public health state of emergency laws are having on this fundamental right.

1 For a timeline of pandemic-related legislation since Emergency Law no. 2020-290 of 23 March 2020 to manage the Covid-19 epidemic see: https: / /www.vie-publique.fr/loi/276818-loi-14-novembre-2020-prolongation-etat-urgence-sanitaire-16-fevrier-2021 (accessed on 22 February 2021).

2 Agamben (2020)

3 More recently, the distinction was made between what is necessary—to protect individuals' physical health—and what is essential. Thus, even though books "are essential ... [they] cannot be deemed basic necessities like food or the products required to maintain economic activity itself". See State Council (Conseil d'État, or CE), order, 13 November 2020, nos. 445883, 445886, 445899, Société Le poirier-au-loup, Monsieur Prats et autres: https:/ / www.conseil-etat.fr/actualites/actualites/dernieres-decisions-referes-en-lien-avec-l-epidemie-de-covid-19 (accessed on 22 February 2021). 
Since 14 March 2020, several executive orders and decrees ${ }^{4}$ have targeted the freedom of worship directly, raising, between the lines, the question of whether the freedom of worship is unique. Since the end of the first lockdown, the restrictions that had been enacted in March to deal with the circumstances have been loosened but not necessarily lifted. In addition, new provisions have been issued every time the health situation has changed, so there is little hope that we will return to the previous situation soon.

It has also become evident since March that "law in the time of the pandemic" can evolve as rapidly as the health situation. Pandemic-related law has been enacted in record time, and most litigation related to this law is being conducted through so-called emergency proceedings, in particular the emergency-civil liberty (référé-liberté) proceeding, which enables an administrative court to order, within forty-eight hours, "all measures necessary to protect a civil liberty that has clearly been seriously and illegally infringed by a public entity or a private organization charged with providing a public service" (Article L. 521-2 of the French Administrative Justice Code). I will focus on the three orders issued by the French State Council in 2020 following emergency proceedings concerning the impact of pandemic-related measures on the freedom of worship: although the vast majority of the religions in France stopped holding services during the two lockdowns without voicing any objections, the Catholic community manifested its disagreement with the terms for recommencing services in May and November, as well as during the lockdown in October $2020^{5}$.

First, several individuals and associations filed petitions with the State Council regarding decree no. 2020-548 of 11 May $2020^{6}$ on lifting the lockdown ${ }^{7}$. According to the decree's implementing terms, religious services could not be held until 2 June 2020, despite the religious holidays that fall in the Spring and "are important for the three religions that have the highest numbers of followers in France" ${ }^{\prime \prime}$. Next, in an order dated 7 November 2020, the State Council reviewed the provisions on practicing one's religion in decree no. 2020-1310 of 29 October 2020, which lifted the lockdown and against which some Catholic associations had also challenged ${ }^{9}$. Third, the latest suit to date challenges decree no. 2020-1454 of 27 November 2020, which loosens the lockdown measures but limits religious services to 30 participants ${ }^{10}$.

The State Council initially threw its full support behind the legislation passed in March not only to manage the "exceptional circumstances", but also to serve "the public interest related to the lockdown measures taken in today's context of overloaded healthcare facilities"11. In the three decisions discussed here, however, it (1) upheld a broad definition of the freedom of worship (although there is some lingering ambiguity), but nonetheless

4 The executive order of 14 March 2020 instituting various measures to combat the spread of the Covid-19 virus; decree no. 2020-293 of 23 March 2020 setting out the general measures needed to manage the Covid-19 epidemic in the context of the public health state of emergency; decree no. 2020-548 of 11 May 2020 setting out the general measures needed to manage the Covid-19 epidemic in the context of the public health state of emergency, then decree no. 2020-618 of 22 May 2020 supplementing decree no. 2020-548 of 11 May 2020 setting out the general measures needed to manage the Covid-19 epidemic in the context of the public health state of emergency; decree no. 2020-1310 of 29 October 2020 setting out the general measures needed to manage the Covid-19 epidemic in the context of the public health state of emergency; and decree no. 2020-1454 of 27 November 2020 amending decree no. 2020-1310 of 29 October 2020 setting out the general measures needed to manage the Covid-19 epidemic in the context of the public health state of emergency.

5 For a sociological analysis, see https:/ / www.lemonde.fr/le-monde-des-religions/article/2020/11/24/le-sentiment-de-privation-de-la-messe-neconcerne-que-les-catholiques-les-plus-zeles_6060905_6038514.html (accessed on 22 February 2021).

6 Decree no. 2020-548 of 11 May 2020, article 10, III: “Type V places of worship are authorized to stay open. All gatherings or meetings inside them are prohibited. Funerals are authorized but are limited to 20 people".

7 CE, order, 18 May 2020, no. 440366, no. 440361-440511, no. 440512, no. 440519. See Fornerod (2020).

8 CE, order, 18 May 2020, no. 440366. Note that "the restrictions on [ ... ] the freedom of religion, and more specifically the right to participate collectively in rites in the above-mentioned institutions, entered into force on 3 November 2020, pursuant to Article 56 of the decree [of 29 October 2020], in particular to allow for All Saints' Day celebrations devoted to commemorating the believers who have died" (Conseil d'État, ordonnance du 7 November 2020).

9 CE, order, 7 November 2020, Association Civitas et autres, nos. 445,825, 445,827, 445,852, 445,853, 445,856, 445,858, 445,865, 445,878, 445,879, 445,887, $445,889,445,890,445,895,445,911,445,933,445,934,445,938,445,939,445,942,445,948$, and 445,955 .

10 CE, order, 29 November 2020, Association Civitas, Conférence des évếques de France et autres, Mgr M., Association pour la messe, nos. 446,930, 446,941, 446,968 , and 446,975 .

11 CE, order, 24 March 2020, no. 439,694. 
(2) showed that it, too, was influenced by circumstances when determining whether the measures limiting the freedom to practice one's religion are proportionate to the goal of protecting public health.

\section{Freedom of Worship and Places of Worship}

In each of its orders discussed here (issued $18 \mathrm{May}^{12}$ and 7 and 29 November 2020), the State Council (Section 2.1) reiterates, in identical terms, that the freedom of worship is a fundamental freedom and (Section 2.2) broadens the scope of that freedom.

\subsection{The Freedom of Worship Is a Fundamental Freedom}

French law reflects a distinction between the freedom of religious conscience and the freedom to worship, such that several texts must be read together to establish the freedom of worship.

That distinction is made first in constitutional law, through Article 10 of the Declaration of the Rights of Man and the Citizen and Article 1 of the French Constitution of 1958, which protect the freedom of conscience and religious pluralism. Before 1974, the year France ratified the European Convention on Human Rights and Fundamental Freedoms (ECHR) Article 14 that protects freedom of thought, conscience, and religion ${ }^{13}$, the only protection for the freedom of worship was in Article 1 of the French law of 9 December 1905 , concerning the separation of church and state. That article enshrines both the freedom of conscience and the freedom of worship, but legislation does not afford the same kind of protection as the Constitution does, and it took more than a century for the freedom of worship to be recognized as a fundamental freedom ${ }^{14}$. More than a decade after that, in the context of a different state of emergency during which the State Council was petitioned several times with respect to the closure of places of worship ${ }^{15}$, it again stated that the freedom of worship is a fundamental freedom, in a recital that it then repeated in each of its 2020 orders and that stands as precedent: "the freedom to worship confers on everyone the right to express the religious convictions of their choosing and includes the freedom to possess and use the items required to practice a religion, subject to compliance with public policy"16.

The State Council has not deviated from this approach to religious freedom during today's public health state of emergency. Instead, it has held that "as established by law, this freedom is not limited to an individual's right to express their chosen religious convictions provided they do so in a manner consistent with public policy. Its fundamental components also include, subject to the same proviso, the right to participate in collective ceremonies, in particular in places of worship"17. In doing so, the Council applies its earlier, broader definition of the freedom of worship, giving it both an individual and a collective dimension. It also goes beyond its previous case law in this respect by not restricting the exercise of this freedom to places of worship.

As in the cases mentioned above related to the closure of Muslim houses of worship during a state of emergency, the State Council innovates by putting individual and collec-

12 CE, order, 18 May 2020, no. 440,366.

13 See Gonzalez (2020), comparing French law, and in particular the State Council's orders of 18 May 2020, with European case law.

14 CE, order, 16 February 2004, no. 264,314, M. Benaissa.

15 Closing places of worship was based on Article 8 of the French law of 3 April 1955, as amended by Article of the law of 21 July 2016, which provides that "[t]he minister of the Interior, for all of the territory subject to the state of emergency, and the prefect, in the department, may order the provisional closure of theaters and performance halls, drinking establishments, and meeting places of all kinds, in particular places of worship in which remarks constituting incitement to hatred, violence, or the commission of acts of terrorism are made or where such acts are advocated, in the areas determined by the decree provided for in Article 2". These provisions have since been included in Law No. 2017-1510 of 30 October 2017 and codified in Article L. 227-1 of the French Code of Domestic Security.

16 CE, order, 6 December 2016, no. 405,476, Association islamique Malik Ibn Anas, concerning the closure of the Ecquevilly mosque: "the freedom of worship is a fundamental freedom which the closure of a place of worship is likely to infringe"; 20 January 2017, no. 406,618 (closure of the Al Rawda mosque in Stains); 11 January 2018, no. 416,398 (closure of the Salle des Indes mosque in Sartrouville); 31 January 2018, no. 417,332 (closure of the As Sounna mosque in Marseille); 22 November 2018, no. 425,100 (closure of the Centre Zahra place of worship in Grande-Scynthe).

17 CE, order, 18 May 2020, no. 440,366, recital no. 11, CE, order, 7 November 2020, Association Civitas et autres, recital no. 10; CE, order, 29 November 2020, Association Civitas, Conférence des évêques de France et autres, Mgr M., Association pour la messe, recital no. 11. 
tive religious practices on equal footing. Whereas the freedom of worship traditionally encompassed only collective practices, it now includes individual practices, which under French law are generally considered a manifestation of the freedom of conscience. For example, the State Council opinion of 3 June 2000 clearly indicates that "whereas like all public employees, public school employees enjoy freedom of conscience .... the principle of secularity (laïcité) prevents them from having a right to manifest their religious beliefs while providing a public service ${ }^{\prime 18}$. Where individuals are concerned, references to freedom of worship have generally required a collective practice in the background, such as in the case that led the State Council to hold that the freedom of worship is a fundamental freedom. In that case, the petitioner worked in a public housing office and contested his employer's refusal to allow him to miss work every Friday from 2 P.M. to 3 P.M. to go to the mosque to pray ${ }^{19}$.

Similar thinking reigns when it comes to the freedom of religion of people who attend chaplaincies in "closed" public establishments such as hospitals and prisons. Chaplaincy services have always been and still are closely related to collective ceremonies as they require, at the very least, a chaplain. In healthcare facilities for example, "hospitalized patients must be able to practice their religion. After sending a request to the facility's administrators, they are visited by the minister of the religion of their choice" (Art. R. 1112-46 of the French Public Health Code). This means more broadly that "everyone must be able to be made capable of participating in worship (contemplation, presence of a minister of their religion, food, freedom of action and expression, funeral rites, etc.)" ${ }^{\prime 20}$. The law on prisons of 24 November 2009 thus grants detainees "freedom of opinion, conscience, and religion" and the ability to "practice the religion of their choice" (Art. 26) ${ }^{21}$. In a case decided in 2016, however, the individual practice of eating halal products was not assessed in the light of the freedom of worship but of the "religious convictions" of the detainee who had filed the claim ${ }^{22}$.

What is particularly interesting about the orders of 18 May and 7 and 27 November 2020 is that they go beyond the earlier cases on closing places of worship and make the right to participate collectively in the ceremonies that take place there "a fundamental component" of the freedom of worship.

\subsection{Religious Buildings Are Places of Worship Par Excellence}

The freedom of worship can clearly be exercised in different places. But as the law arising from the health crisis-as interpreted by the State Council-has reminded us, religious buildings are inherently well suited to hosting religious worship.

The idea that religious buildings are places of worship par excellence comes to us directly from the revolutionary period, which inaugurated a strictly understood conception of worship: religious services could be held only in the buildings designed for them ${ }^{23}$. By providing that "the services of any religion are prohibited outside the premises chosen for their exercise" (Art. IV), the decree of 3 ventôse year III (21 February 1795) created a close link between place and function. Less radically, the State Council echoed that decree two centuries later when it held that a structure is a religious building when it is used "exclusively and permanently" for religious ceremonies ${ }^{24}$. Places devoted to worship are therefore the natural setting for exercising the freedom of worship, but that setting became an empty shell during lockdown. Although gatherings or meetings of up to 20 people were briefly authorized in religious establishments (executive order of 14 March 2020), they were

18 CE, opinion, 3 June 2000, no. 217,017, Mlle Marteaux.

19 CE, order, 16 February 2004, no. 264,314, M. Benaissa.

20 Memo, 2 March 2006, on the rights of hospitalized individuals and including a hospitalized person's charter, NOR: SANH0630111C.

21 Like other collective activities in prisons, "worship" was suspended during lockdown. See, inter alia, CE, order, 8 April 2020, no. $439,827$.

22 CE, 10 February 2016, no. 385,929.

Messner et al. (2003).

24 CE, 19 July 2011, no. 313,518, Commune de Montpellier. 
eventually prohibited, "except for funerals limited to 20 people", by the decree of 23 March 2020 (Art. 8, IV).

In particular, the 23 March decree ushered in a period during which only individual visits to religious buildings were allowed, ignoring the inherent collective dimension of the freedom of worship and the central role played by religious ministers in various religious traditions. From this perspective, it is probably not insignificant that in the first case to give rise to a State Council ruling concerning places of worship in 2020, the petitioner requested the suspension of the orders of 14 and 15 March 2020 because "they prohibit the practice of religions as well as the ability to enter into contact, inside religious buildings, with religious ministers ${ }^{25}$ ". In this regard, the European Court of Human Rights (ECtHR) has several times found that "religious ceremonies have their meaning and sacred value for the believers if they have been conducted by ministers empowered for that purpose in compliance with these rules. The personality of the religious ministers is undoubtedly of importance to every member of the community. Participation in the life of the community is thus a manifestation of one's religion, protected by Article 9 of the Convention" ${ }^{26}$. From this point of view, the State Council interprets the decree of 2 October 2020 fairly broadly in its order of 7 November: whereas the decree expressly authorizes only "funerals limited to 30 people" in places of worship (Art. 47), the Council holds that "religious ministers may continue to welcome believers [there] individually" (recital no. 16).

Even though the law of 23 March 2020 instituting a public health state of emergency "exempts religious buildings from the injunction to close temporarily that applies to other categories of establishments open to the public and public meeting places" 27 , services other than funerals (limited to 20 participants) were prohibited. The colorless, ersatz services developed in response to that prohibition highlight that the exemption was merely symbolic, casting doubt on the close connection between the freedom of worship and religious buildings, and more importantly, on the fact that the services held there constitute the very essence of worship. This is especially true since these buildings were not considered establishments open to the public "that supply the goods and services required to satisfy basic needs" (Art. 2, Law no. 2020-290 of 23 March 2020) and it was not until the decree of 27 November 2020 took effect that going to a place of worship became an expressly authorized reason for people to leave their homes during lockdown. The State Council's order of 7 November was probably taken into account, because on this issue it had said that "the statements made by the government during the hearing [indicate] that instructions have been given so that believers may go to the place of worship closest to home or within a reasonable distance by checking the 'pressing family reasons' box on the permission slip" $^{\prime 28}$ (recital no. 16).

Until the decree of 27 November 2020 took effect, only religious funerals were expressly exempt from the prohibition on religious services, such that "funeral rites, which in Europe are one of the last sources of the social legitimacy of churches" ${ }^{29}$, have been closely associated with religious buildings since mid-March even though, for sanitary reasons, many funeral-related activities (e.g., preparing the dead for burial or cremation) have simply been suspended. Funerals were thus the primary link between religious buildings and the exercise of religious freedom until the State Council, in its order of 18 May 2020, restored those buildings to their primary purpose (subject to conditions) for the first lockdown lifting ${ }^{30}$.

25 CE, order, 30 March 2020, no. 439,809. The central role assigned to religious ministers has been interpreted as evidence of a certain clericalism (see Rauwel (2020), whereas the Catholic Church has been talking about this for a number of years, if not decades, because of the decreasing number of priests. See Borras (2001).

26 ECtHR, Gd. ch., 24 October 2000, no. 30,985/96, Hasan and Chaush v Bulgaria, para. 62.

27 Fialaire (2020).

28 Translator's note: To leave their homes during lockdowns, residents of France must fill out a form that contains nine legitimate reasons to go out. Failure to have a correctly filled out form result in a $€ 135$ fine.

29 Rauwel (2020).

30 More precisely, the State Council holds that "the Prime Minister has a period of eight days to take measures strictly proportionate to the health risks incurred and appropriate to the circumstances of time and place applicable at the beginning of the lockdown lifting" (recital 36). 
Lastly, in its order of 7 November, the State Council interprets the decree of 2 October 2020 particularly broadly. That decree expressly authorizes only "funerals limited to 30 people" in places of worship (Art. 47), but the Council finds that "religious ministers and everyone who may be deemed their personnel" may attend religious services, "in particular to make sure they are broadcast, while following the so-called protective measures and in particular wearing a mask, which may momentarily be removed to accomplish the rites that require it" (recital no. 16). This recital refers to the important role televised broadcasting of religious services came to play during the first lockdown and illustrates how the State Council takes into account numerous factors that have concretely characterized the exercise of worship since the beginning of the pandemic.

\section{A Fact-Based Approach to Worship}

A detailed analysis of the material conditions for worshipping is a thread running through all three orders. This approach is to be expected. As discussed in Section 3.2 below, the issue is whether or not exercising the freedom of worship is compatible with the goal of protecting the physical health of the individuals targeted by the challenged decrees. Less expected, however, is (Section 3.1) the terminological effect these decrees have on the State Council's decisions.

\subsection{Unusual Terminology Related to Places of Worship}

The State Council is no stranger to disputes involving religious buildings, whether the issue is their construction, preservation, or use, and it has developed abundant case law in this regard over several decades ${ }^{31}$. Despite that expertise, in the three orders issued in 2020 , it borrows terminology from the decrees related to combating Covid-19, which reflect the view that individuals are essentially, if not exclusively, physical rather than spiritual beings. The public health legislation has thus had an unanticipated terminological effect.

First, the term "religious establishments" has been used in the decrees adopted since mid-March and, to a lesser degree, in the case law, where it coexists with the classic terms "places of worship" and "religious buildings". "Religious establishments" is the term used in safety-related legislation (on the risks of fire and panic in establishments open to the public) based on the executive order of 25 June 1980. Although it cannot be said that the decrees clearly intend to separate religious buildings from their fundamental function of providing a place for people to exercise their freedom of worship, the terminology leads them to be read solely through the lens of safety, thus equalizing religions to some extent when, in fact, different religious buildings have different statuses ${ }^{32}$. Over the course of the year, however, there was a slight shift in terminology. Whereas decree no. 2020-293 of 23 March 2020, setting out the general measures needed to manage the Covid-19 epidemic in the context of the public health state of emergency, almost cavalierly included places of worship among "establishments open to the public" (articles 8 to 10), the decree of 29 October is more deferential and devotes a separate chapter to them, providing that "[r]eligious establishments, falling within category V, are authorized to stay open. All gatherings or meetings inside them are prohibited except for funerals limited to 30 people" (chapter 6: Religions, article 47).

Similarly, the "manager of the place of worship" is assigned an important new role, namely, to implement the measures "necessary to manage the Covid-19 epidemic", such as physical distancing and mask wearing, provided for by decree no. 2020-618 of 22 May 2020 supplementing decree no. 2020-548 of 11 May 2020. In wording subsequently reused in the decrees of 29 October and 27 November 2020, this decree provides that "the manager of the place of worship ensures compliance at all times, and in particular on entering and exiting the building", with the requirement to wear a protective mask starting at age

31 In addition to the cases mentioned in footnote 16, case law on places of worship can be found in the minister of the Interior's memo, 19 July 2011 , on Places of worship: ownership, construction, repair and maintenance, town planning rules, taxation, NOR/ICO/D/11/21246C.

32 See, e.g., Ministry of the Interior memo NOR/IOCD1121246C of 29 July 2011. Religious buildings: ownership, construction, repair and maintenance, urban planning rules, taxation, available at: https://legirel.cnrs.fr/IMG/pdf/110729.pdf (accessed on 22 February 2021). 
11 and to limit on the number of individuals admitted to a religious service. The extent of this promotion of the "manager" of a place of worship is clear in the State Council's order of 29 November. The "manager's" new role arises from the fact that "it has been established that for public health reasons, there is a need to regulate, pursuant to Article L. 3131-15 of the Public Health Code ${ }^{33}$, the conditions for entering and remaining in religious establishments, in particular in this early period of easing the lockdown conditions" (recital no. 17). More importantly, the Council finds that the authority of "the manager of the place of worship" prevails over that of "religious ministers with respect to practicing their religion" (which is based on the provisions of Article 5 of the law of 2 January 1907 on the public exercise of religions). In so doing, the Council breaks, in the name of public health, with earlier case law granting important prerogatives to religious ministers in organizing places of worship 34 .

\subsection{Freedom of Worship and Protection of Health}

As with any civil liberty, there are limits to exercising one's right to worship. In the context of the Covid-19 pandemic, freedom of worship must "be reconciled with the goal of protecting health, which is a constitutional right ${ }^{\prime \prime 35}$. It has been noted that the legal measures (especially the first ones) taken to combat the pandemic tended to reduce life and human health to their biological dimension, which must be protected and nourished in the literal sense. This approach has two tangible effects on the State Council's orders: both religious services and places of worship are viewed through the lens of behaviors likely to spread the virus.

With respect to religious services, not only does the State Council ignore their spiritual dimension and theological scope, but it also seems to dissect them and consider only their physical features. For example, in its orders of May and November 2020, the Council finds that "religious services that constitute gatherings or meetings within the meaning of the challenged provisions expose the participants to a risk of infection, which is increased because the services are held in an enclosed area of limited size over a significant amount of time with a large number of individuals, and are accompanied by prayers said aloud or by singing, as well as ritual gestures that involve contact, movement, or exchanges between participants, including on the margins of the services themselves" ${ }^{\prime 36}$.

This approach is not at all consistent with the solemnity of the recital in the three orders, which proclaims that a broadly understood freedom of worship is a fundamental freedom and implies that practices other than services in religious buildings are key components of that freedom ${ }^{37}$. Nor is it consistent with settled European and French case law, according to which collective religious practices such as funerals (protected under the freedom of religion ${ }^{38}$ ), gatherings and meetings (protected as a form of worship ${ }^{39}$ ), and processions and pilgrimages may take place outside religious buildings. While the State Council does not explicitly assign a hierarchy to "the essential components" of the freedom of worship, the wording of the recitals in the order of 18 May 2020 implies one.

33 That article provides that "in territorial districts where a public health emergency has been declared, the Prime Minister may, by a regulatory decree issued on the basis of the health minister's report, for the sole purpose of protecting public health: ... $5^{\circ}$ Order the provisional closure and regulate the opening of one or more categories of establishments open to the public as well as places of worship, including the conditions for entering and remaining in them, by providing individuals with access to goods and services of basic necessity".

34 See Fornerod (2013), discussing the powers of religious ministers in places of worship, and Catholic churches in particular.

35 CE, order, 18 May 2020, no. 440,366.

36 CE, order, 18 May 2020, no 440,366, recital no. 27 and CE, order, 29 November 2020, Association Civitas, Conférence des évêques de France et autres, Mgr M., Association pour la messe, nos. 446,930, 446,941, 446,968, 446,975, recital no. 15.

37 In a way, however, this recital could have been understood to establish an "internal hierarchy" within the freedom of worship, "other aspects of religious life [being] downgraded to the rank of 'minor components' of the freedom of worship". See Fialaire (2020) and also, in the same sense, Gonzalez (2020).

38 The European Court of Human Rights clearly states that "the manner of burying the dead and cemetery layout represents an essential aspect of the religious practice": ECtHR, Johannische Kirche and Peters v. Germany, 10 July 2001, no. 41,754/98.

39 It has thus been held with respect to the Limousin ostensions that they consist "in the solemn presentation by the clergy of relics of saints who are from or who lived in Limousin, with veneration of those relics by the believers and occur during Christian religious services such as processions and eucharist; they therefore constitute a religious practice". CAA Bordeaux, 21 December 2010, no. 10BX00634. 
For example, the Council finds that the prohibition on outdoor gatherings in public places does not, "in its generality or with regard to religious activities in particular, seriously and clearly illegally infringe a fundamental freedom" (recital no. 38) and the Prime Minister is not enjoined to reauthorize them.

This decision seems doubly paradoxical given that the goal is to limit the spread of Covid-19. Due to the "lack of alternatives to protect the freedom of worship" (recital no. 36), after noting that "religious services expose the participants to a risk of infection, which is increased because the services are held in an enclosed area of limited size over a significant amount of time" (recital no. 27), the State Council enjoins the Prime Minister to amend the provisions of decree no. 2020-548 of 11 May 2020 that maintain the prohibition on gatherings and meetings in religious establishments ${ }^{40}$. The uniqueness of the circumstances is undeniably at play here. The approach to religious worship is much more functional than in the decisions addressing the May 2020 lockdown-lifting measures or the lockdown easing in November 2020, both of which raised the issue of whether a place of worship is a place of infection like any other.

More specifically, in the three orders issued in 2020, the State Council finds that the way in which religious services are carried out exposes the participants to a risk of infection. But the petitioners also complained that the lockdown and lockdown-lifting measures were implemented differently for different activities, so the Council had to rule on those differences. Given the public health situation at the time, the justification for the second lockdown (which began on 29 October 2020) did not require a long explanation: allowing certain activities to continue was designed "to avoid the most harmful economic and social effects that had been observed during the first lockdown" (order of 7 Nov., recital no. 18). However, the comparison with other activities or other places in which there was a risk of spreading the virus worked to the petitioners' advantage when both lockdowns were lifted. In May 2020, the State Council noted that there were fewer restrictions on public access regarding many activities, such as transporting travelers, or for "stores and shopping centers, educational institutions, and libraries which, for economic, educational, and cultural reasons, are open to the public while complying with the provisions applicable to them" (recital no. 31). More importantly, in the midst of several practical and technical considerations, it couches its reasoning in terms of civil liberties, underscoring that "if, during the first phase of lifting the lockdown, gatherings and meetings are not authorized in establishments open to the public other than places of worship, [it is because] the activities carried out in them are not of the same type and the fundamental freedoms at stake are not the same" (recital no. 32). The Council then uses similar wording in the order of 2 November 2020 to enjoin the government to repeal the 30-person limit on religious services ${ }^{41}$.

\section{Conclusions}

Ultimately—and surely inevitably—-the public health situation set a special tone for these State Council decisions. Nonetheless, the orders of 18 May and 29 November freed worship from the constraints of strict compliance with the measures arising from solely health-related concerns. Moreover, they enabled the State Council to reiterate the fundamental link between the freedom of worship and religious buildings.

Despite the context of the public health state of emergency, the State council has, to some extent, not deviated much from a classic reasoning aimed at combining freedom of worship and public policy. In this regard, the orders of 18 and 29 November 2020 are in line with previous case law on religious buildings.

40 CE, order, 18 May 2020, no. 440,366.

41 On 2 December 2020, a press release issued by the ministry of the Interior indicated that every third seat and every other row may now be occupied in places of worship. Ministry of Interior Press Release of 2 December 2020, Organisation des cérémonies religieuses durant la deuxième phase de confinement: https:/ / www.interieur.gouv.fr/Actualites/Communiques/Organisation-des-ceremonies-religieuses-durant-la-deuxieme-phase-deconfinement (accessed on 22 February 2021). 
In addition, through those orders, the State Council provides a kind of instruction manual for places of worship in the current period. Unless the general health situation in France deteriorates and requires a new and particularly strict lockdown, there is no reason for the legal framework for religious celebrations to change for the time being and to expect other litigations.

One question remains open, however. One may indeed wonder what will happen to the above-mentioned terminological impact of the measures to combat the spread of the Covid-19 virus. Will the courts continue to consider religious buildings as mere "religious establishments ", with its consequences for the management of celebrations, or will they revert to pre-pandemic terminology?

Funding: This research received no external funding.

Institutional Review Board Statement: Not applicable.

Informed Consent Statement: Not applicable.

Data Availability Statement: Not applicable.

Acknowledgments: This article was translated from French into English by Naomi Norberg.

Conflicts of Interest: The authors declare no conflict of interest.

\section{References}

Agamben, Giorgio. 2020. Una Domanda. April 14. Available online: https://www.quodlibet.it/giorgio-agamben-una-domanda (accessed on 3 December 2020).

Borras, Alphonse. 2001. Considérations canoniques sur la vie liturgique dans la nouvelle paroisse. Esprit Et Vie 34: 7.

Fialaire, Jacques. 2020. Liberté de culte et urgence sanitaire: Les leçons de la jurisprudence. Jurisclasseur Périodique A, 2155.

Fornerod, Anne. 2013. Le Régime Juridique Du Patrimoine Religieux. Paris: L’Harmattan.

Fornerod, Anne. 2020. Les édifices cultuels et la liberté de culte pendant l'état d'urgence sanitaire. Revue du Droit Des Religions 10: 175-85. Available online: https://journals.openedition.org/rdr/1268 (accessed on 22 February 2021). [CrossRef]

Gonzalez, Gérard. 2020. Covid19: Le Conseil d'État au chevet de la liberté de culte. Jurisclasseur Périodique Général, 717.

Messner, Francis, Pierre-Henri Prélot, and Jean-Marie Woehrling, eds. 2003. Traité De Droit Français Des Religions. Paris: Litec, pp. 4-5.

Rauwel, Alain. 2020. Les Pratiques Rituelles Par Temps De Pandémie. April 9. Available online: https://www.ehess.fr/fr/carnet/ coronavirus / pratiques-rituelles-par-temps-pandémie (accessed on 22 February 2021). 